\title{
Land Productivity Of A Traditional Market In Urban Area
}

\author{
Christiono Utomo ${ }^{1, *}$, Yani Rahmawati ${ }^{2}$, Tatang Akhmad Taufik ${ }^{1}$, Cahyono B. Nurcahyo ${ }^{1}$, Dian Pararta Laksmi $^{1}$ \\ ${ }^{1}$ Department of Civil Engineering, Institut Teknologi Sepuluh Nopember (ITS), Surabaya, Indonesia \\ ${ }^{2}$ Department of Civil and Environmental Engineering Universiti Teknologi PETRONAS, Malaysia
}

\begin{abstract}
A land requires use analysis to obtain the best increase in the land value. Likewise with the land of an urban traditional market. Highest and Best Use (HBU) analysis is needed to get the best alternative property on the land. A traditional market is one place where the activity of trading centre. However, along with the development of the era of the existence of traditional markets increasingly abandoned. One of them is Pucang Anom market located in Pucang Anom Street, Surabaya. Market conditions on the second floor are quiet and lack of interest. In addition, the market conditions are old and look shabby. Therefore, it is necessary to revive Pucang Anom market so that it can produce the highest land value. Alternative land use is analysed using HBU method. The analysis began with an explorative study to explore alternatives of land use, afterwards it continued with four stages analysis including regulatory compliance and permits, possibility and affordability of construction, financial feasibility, and maximum productivity of land. The results of this study found an alternative mixed use between market and apartment as the best options with the highest land value and maximum productivity is $210 \%$.
\end{abstract}

\section{Introduction}

An urban market is defined as an area where the sale and purchase of goods with a number of sellers more than one. It is well known as shopping centres, traditional markets, shops, malls, plazas, trade centres and other designations. They are markets that are built and managed by a government, a local government, a private company, state-owned enterprises and regionally-owned enterprises including cooperation with the private sector. For a traditional markets, the place is in the form of shops, kiosks, stalls and tents that are owned or managed by individual, a small-medium enterprise and nongovernmental organizations. The business is small-scale, small capital and with the process of buying and selling merchandise through bargaining

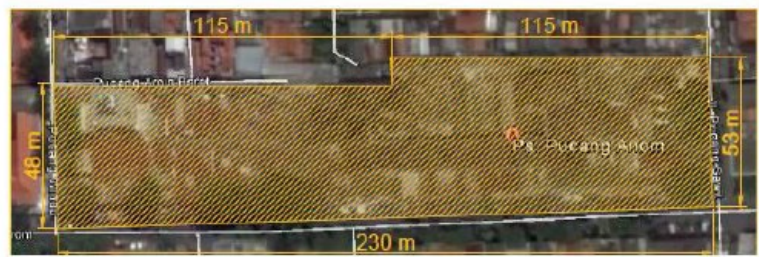

Fig. 1. The size of Pucang Anom market land.

There are many traditional markets whose location is not in accordance with the initial plan of development due to the development of the city. As a result the traditional market function is not optimal. One example is Pucang Anom market Surabaya. It has a land area of $11,615 \mathrm{~m} 2$ and building area of 12,000 m2 (See Fig.1). Market conditions are old, dirty, shabby, and insufficient parking capacity. This resulted in uncomfortable market conditions. Kiosk on the first floor consisting of fruits, vegetables, meat and food stalls, the situation is very crowded. Meanwhile Kiosk on the second floor is not much of visitors. It is influenced by the location of the market surrounded by commercial property that resulted in decreasing public interest to visit the market. Therefore it is necessary to revitalize Pucang Anom market by using the highest and best land analysis as the initial stage to understand the revitalization without eliminating the existence of traditional markets as the main function of a public facility.

\section{Concept and Method}

This research used qualitative and quantitative method. Quantitative method was applied by implementing the principle of HBU. The determination of alternative building functions is done through stakeholder analysis. The analysis began with the determination of key stakeholders, whom are representatives of property management, city government, urban experts and 20 traders in traditional market who are chosen randomly as sample research. The quantitative method was applied for legal and physical analysis to get the maximum capacity of building. The quantitative was also applied for financial analysis using cash flow, market value, and productivity analysis [2].

The HBU is defined as the possible legal and logical use of an empty or upgraded property, which physically, reasonably, and financially allow it to deliver the highest value [3]. Cited from The Society of Residential (SSA), the HBU is a concept of appraisal that can be applied to lands or buildings which is usually interpreted as land use which will maximize the wealth of the owner through the most profitable use of the land [4].

* Corresponding author: christiono@ce.its.ac.id 
HBU process is usually done in sequence. Only alternative determination steps can be done before or at the time of completion of legal receipts that are highly dependent on the decision whether illegal use is considered [5]. The maximum productivity of a land is the use that results in the highest value of the difference between the pre-use value and after use, or the highest and consistent residual value. The value of land is obtained by the market capitalization rate. Revenue earned from development is subtracted from net income from total property. The remaining income is land residual technique. With this method, the market value of the land can be known if the value of the relatively new building market can be known with certainty.

Some methods in measuring the value of buildings are by using cost approach and market data approach in the context of cost estimation. The value of the property can be obtained from NOI (Net Operating Income) or NOI divided by capitalization rate that are obtained from the aggregation of expectations against the rate of return. Finally the value of the land can be calculated by subtracting the property value with the value of the building [6].

The research variables can be seen in Table 1. It presents the combination variables from $\mathrm{HBU}$.

Table 1. Research variables.

\begin{tabular}{|c|c|c|}
\hline Variables & Indicators & Data \\
\hline Alternatives & $\begin{array}{c}\text { Alternative used of the } \\
\text { land }\end{array}$ & Primary data \\
\hline Legal aspect & $\begin{array}{c}\text { Zoning and } \\
\text { Building code }\end{array}$ & Secondary data \\
\hline $\begin{array}{c}\text { Physical } \\
\text { aspect }\end{array}$ & $\begin{array}{c}\text { Location, Land size, } \\
\text { Accessibility, and } \\
\text { Utility }\end{array}$ & $\begin{array}{c}\text { Primary and } \\
\text { secondary data }\end{array}$ \\
\hline $\begin{array}{c}\text { Financial } \\
\text { aspect }\end{array}$ & $\begin{array}{c}\text { Capital expenditure, } \\
\text { Operation expenditure, } \\
\text { Revenue, Terminal } \\
\text { vale, Cash flow, } \\
\text { Capital budgeting }\end{array}$ & Secondary data \\
\hline $\begin{array}{c}\text { Productivity } \\
\text { maximum }\end{array}$ & Land value & Secondary data \\
\hline
\end{tabular}

\section{Result and Discussion}

There are two stages in the analysis of this study which are determination of development alternatives through stakeholder analysis, and stage of HBU analysis. The analysis phase of determining the alternative of this type of land use is done through interviews and questionnaires to stakeholders who are directly involved in the utilization [7] of Pucang Anom market land. Furthermore, to determine the alternatives that will provide the highest and most economically profitable land market value, each of these alternatives is then tested using the four criteria and the HBU principles [9], which are legally permissible, physically possible, financially feasible, and maximally productive.

\subsection{Legal aspect}

Based on stakeholders' interviews, it is found 4 alternatives that are determined on Table 2

Table 2. The alternatives.

\begin{tabular}{|c|c|}
\hline Number & Use \\
\hline Alternatives one & $\begin{array}{c}\text { Traditional market } \\
\text { Shopping centre } \\
\text { Food centre } \\
\text { Apartment } \\
\text { Hotel }\end{array}$ \\
\hline Alternatives two & $\begin{array}{c}\text { Traditional market } \\
\text { Shopping centre } \\
\text { Food centre }\end{array}$ \\
\hline Alternatives three & $\begin{array}{c}\text { Traditional market } \\
\text { Apartment }\end{array}$ \\
\hline Alternatives four & $\begin{array}{c}\text { Traditional market } \\
\text { Hotel }\end{array}$ \\
\hline
\end{tabular}

The legal acceptance test is a selection process for all possible use of alternatives that are involving requirements that comes out from principles of the prevailing regulations in the related area. They are analysed whether they are and still valid or planned to be temporary regulations. The analysis is based on some criteria that consist of private restriction, zoning, building codes, and environmental regulation. Table 3 shows the result of legal acceptance analysis.

Table 3. Result of legal aspect

\begin{tabular}{|c|c|c|c|c|}
\hline \multirow{2}{*}{$\begin{array}{c}\text { Legal } \\
\text { criteria }\end{array}$} & \multicolumn{4}{|c|}{ Alternatives } \\
\cline { 2 - 5 } & one & two & three & four \\
\hline $\begin{array}{c}\text { Private } \\
\text { restriction }\end{array}$ & Allowed & Allowed & Allowed & Allowed \\
\hline Zoning & Allowed & Allowed & Allowed & Allowed \\
\hline Building Codes & Allowed & Allowed & Allowed & Allowed \\
\hline $\begin{array}{c}\text { Environment } \\
\text { regulation }\end{array}$ & Allowed & Allowed & Allowed & Allowed \\
\hline
\end{tabular}

\subsection{Physical aspect}

Analysis on this physical aspect consists of location, land shape, accessibility and availability of facilities. Each alternative is analysed to find out if it is possible to build on existing physical aspects.

First is location. The land is located in the middle of the city of Surabaya and it is adjacent to commercial areas such as shops, offices, banks and also residential area. It is suitable to be developed into a commercial property.

The second is land shape and size. The land has an area of $11,615 \mathrm{~m} 2$, and the size of the land is rectangular so it makes it easy to be developed into an expected property such as apartments, food courts, hotels, and shops. 
The third is utility. To support property activities such as traditional markets, apartments, food courts, shops, and hotels, availability of utility networks and infrastructure is a must. The land has supporting facilities such as water, electricity and telephone lines so that it is possible to build the expected alternative properties.

The fourth is land accessibility. The land is reviewed from the function of road and availability of public transportation. Based on research directly into the object of research, the existence of public transportation such as city transportation and taxis are available

The result is presented in Table 4.

Table 4. Result of physical aspect

\begin{tabular}{|c|c|c|c|c|}
\hline \multirow{2}{*}{$\begin{array}{c}\text { Physical } \\
\text { criteria }\end{array}$} & \multicolumn{4}{|c|}{ Alternatives } \\
\cline { 2 - 5 } & one & two & three & four \\
\hline Location & Possible & Possible & Possible & Possible \\
\hline Shape and size & Possible & Possible & Possible & Possible \\
\hline Utility & Possible & Possible & Possible & Possible \\
\hline $\begin{array}{c}\text { Land } \\
\text { accessibility }\end{array}$ & Possible & Possible & Possible & Possible \\
\hline
\end{tabular}

\subsection{Financial aspect}

Analyse the investment by taking into account the cost of land preparation, construction costs (building costs and fixed equipment costs), professional service fees, administration fees, and other costs. From the calculation on the financial feasibility analysis, the net present value (NPV) can be obtained from capitalization rate of own capital. The capitalization rate of loan capital is equal to $10.75 \%$. The results of financial revenue analysis are presented in Table 5.

Table 5. Result of legal aspect

\begin{tabular}{|c|c|c|c|c|}
\hline $\begin{array}{c}\text { Financial } \\
\text { criteria }\end{array}$ & \multicolumn{4}{|c|}{ Alternatives } \\
\cline { 2 - 5 } & one & two & three & four \\
\hline \multirow{2}{*}{ NPV } & $\begin{array}{c}18 \\
\text { million } \\
\text { USD }\end{array}$ & $\begin{array}{c}40 \\
\text { million } \\
\text { USD }\end{array}$ & $\begin{array}{c}115 \\
\text { million } \\
\text { USD }\end{array}$ & $\begin{array}{c}-40 \\
\text { million } \\
\text { USD }\end{array}$ \\
\hline Decision & Feasible & Feasible & Feasible & $\begin{array}{c}\text { Not } \\
\text { feasible }\end{array}$ \\
\hline
\end{tabular}

\subsection{Productivity maximum}

The concept of maximum productivity was used to measure how high the value of land after the development. Using the residual value method, the value of land depends on the potential for development on the land. It is determined by gross development value, total development value, and minimum profit requirements. The productivity of land is approximately $60 \%-160 \%$ higher than traditional market without development.

The financial calculation is based on investment rate of return and cost of capital [2]. The capital structures are equity (25\%) with cost of capital is $9 \%$ and loan $(75 \%)$ with cost of capital is $12 \%$. The minimum attractive rate of return (MARR) investment is calculated using weighted average cost of capital (WACC) method,

Building capitalization rates were used to determine the estimated market value of the land as a benchmark for maximum productivity. If the market value of land after development is higher than the market value of land without development, then the mix-use building is feasible to be developed. Based on the results of the maximum productivity analysis, there are three mix-used alternatives that have a high level of land productivity. Only one alternative is not feasible that is diversification of market businesses and hotel. Table 6 presents the calculation of the estimated market value of land in each mix-use building.

Table 6. Calculation of land productivity

\begin{tabular}{|c|c|c|c|c|}
\hline \multirow{2}{*}{ Variables } & \multicolumn{4}{|c|}{ Alternatives } \\
\cline { 2 - 5 } Property value & $\begin{array}{c}\text { one } \\
\text { two } \\
\text { million } \\
\text { USD }\end{array}$ & $\begin{array}{c}370 \\
\text { million } \\
\text { USD }\end{array}$ & $\begin{array}{c}458 \\
\text { million } \\
\text { USD }\end{array}$ & $\begin{array}{c}222 \\
\text { million } \\
\text { USD }\end{array}$ \\
\hline Building value & $\begin{array}{c}183 \\
\text { million } \\
\text { USD }\end{array}$ & $\begin{array}{c}175 \\
\text { million } \\
\text { USD }\end{array}$ & $\begin{array}{c}153 \\
\text { million } \\
\text { USD }\end{array}$ & $\begin{array}{c}209 \\
\text { million } \\
\text { USD }\end{array}$ \\
\hline Land value & $\begin{array}{c}160 \\
\text { million } \\
\text { USD }\end{array}$ & $\begin{array}{c}195 \\
\text { million } \\
\text { USD }\end{array}$ & $\begin{array}{c}305 \\
\text { million } \\
\text { USD }\end{array}$ & $\begin{array}{c}13 \\
\text { million } \\
\text { USD }\end{array}$ \\
\hline Land value/m2 & $\begin{array}{c}1.3 \\
\text { million } \\
\text { USD }\end{array}$ & $\begin{array}{c}1.6 \\
\text { million } \\
\text { USD }\end{array}$ & $\begin{array}{c}2.6 \\
\text { million } \\
\text { USD }\end{array}$ & $\begin{array}{c}0.1 \\
\text { million } \\
\text { USD }\end{array}$ \\
\hline Productivity & $163 \%$ & $198 \%$ & $210 \%$ & $87 \%$ \\
\hline
\end{tabular}

Table 6 shows that alternative three is the best alternative in term of land productivity. HBU analysis of the land and building of Pucang Anom market in Surabaya generate a comparison of traditional market between with market business diversification and without addition to market development.

\section{Conclusion}

Based on the results of the analysis and calculation, the best market use of land is mixed used between traditional markets and apartments. The increase in productivity is $210 \%$ or 2.1 times. The approach that is applied in this research is the best practice to determine the best use of traditional market land in urban area.

The authors appreciate the recognition and awards in forms of research grant and fellowship from "Penelitian Dasar Unggulan Perguruan Tinggi (PDUPT) 2018 based on contract number 869/PKS/ITS/2018" 


\section{References}

1. A.L. Krause, C. Bitter, Cities 29(2) 9-25 (2012).

2. M.E. Miles, M.N. Laurence, S. Adrienne, Real estate development: principles and process, $5^{\text {th }}$ ed. (2015)

3. The Appraisal Institute the Appraisal of real estate, $12^{\text {th }}$ ed. (2001)

4. T.V. Grissom, the Appraisal J 51(1) 45-57 (1983).

5. R.C. Kyle, Property management (2005).

6. M.R. Rattermann, the Appraisal J winter 23-25 (2008).

7. S. F. Fanning, Market Analysis for Real Estat, (Appraisal Institute, Chicago, 2005) 